\title{
Guardians of contested borders \\ Transnational Strategies for Coptic Survival
}

By Lise Paulsen Galal

Coptic interpretations of the status of Copts in Egypt affect their trans-national strategies and their gender constructs embedded in their minority discourses. In particular, different Coptic transnational organisations and their negotiations of Coptic identity are influential.

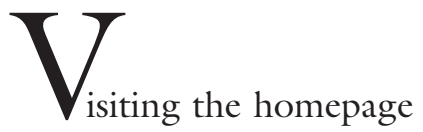

of the U.S. Copts Association, a secular American Coptic organisation, it was possible until recently to read under the headline 'Discrimination News' about the forced conversion of Coptic girls in Egypt to Islam. ${ }^{1}$ The stories on these homepages of Christians originating in Egypt were dramatically presented with pictures and short narratives about each converted girl. In contrast, when visiting American, European and Egyptian Coptic Orthodox Churches' homepages, also addressing Copts outside Egypt, an expansive amount of material concerning relations before marriage and marriage in a Christian framework appeared, but not one word about forced conversion.

The two different presentations of what is essential knowledge about Coptic reality for Copts living outside Egypt reflect two different transnational strategies among the Coptic minority: a strategy focused on human rights and a strategy based on religion. 
The former attempts to influence Copts as well as non-Copts to join the struggle for equal rights for Copts, while the latter attempts to influence Copts to maintain their commitment to Coptic religious identity and beliefs. Both strategies can be seen as taking advantage of a transnational space, but with rather different outcomes, and differing constructs of gender. In the first example, Coptic women are victimised by Muslim assault, in the second, they are defined in relation to marriage and family life. But why are gender constructs elaborated upon in the transnational field and how do the two strategies relate to one another and to the transnational field of which they are a part?

The main focus in this paper is the attempt of Coptic transnational organisations to legitimise and implement their transnational strategies and the way that gender constructs are useful in these processes. After a presentation of the analytical and theoretical approach in the following section, I will describe recent Coptic migration, followed by an analysis of gender constructs in the transnational strategies of secular Copts and the Coptic Orthodox Church respectively. Finally, I will discuss the implications of these constructs for transnational belonging.

\section{FROM MINORITY TO TRANSNATIONAL STUDIES}

From the perspective of minority studies the concept of transnationalism and transnational identities are indispensable for a full understanding of a migrant group. Minority studies have defined the minority as a non-hegemonic or non-dominant group characterised by its relation to the national majority. ${ }^{2}$ By definition, this perspective places a minority in the position of a subordinate or inferior group. In addition, concepts connected to the situation of migrants have an implicit logic that places them in a subordinate position, including concepts such as: diaspora, liminality, hybridity, and difference (Grossberg 1998). In their original meanings, these concepts, which define the abnormal in opposition to the normal identity, contain a sense of disaster, crisis or conflict compared to the nationally rooted, territorial, complete, and pure identity, also referred to as natural identity (Cohen 1997, Mallki 1992). It is possible to reject concepts like diaspora and liminality as exclusively describing a minority situation. As far as the majority goes, it is no more culturally pure than the minority. Neither is a nationally rooted identity more natural than non-territorialised identities. The social and human sciences risk ignoring subject positions and cementing the inferior position of the minority by using these concepts to identify the minority (Grossberg 1998).

Nevertheless, concepts like minority, diaspora, liminality, hybridity, and difference have been concepts useful in identifying non-equal distribution of power between groups of people due to ethnic, national, religious, or other stigmas. The effort to find adequate concepts is important as long as it focuses on the distribution of power, not only between the majority and the minority, but also within the minority group. The concept of transnationalism re-invigorates this concept of power back into migration and minority studies. Life as a diaspora group is not only about being in a marginalised position; it also gives rise to new transnational identities and strategies. One of the questions originating from the transnational perspective is the potential of the transnational community to transgress the powerful position of the National State to exclude the minority. In other words, the transnational field might offer a space for the re-negotiation of the inferior identity of the minority within the borders of the national state. The risk of this approach is, on the other hand, that it can become a celebration of transnational deterritorialised identities that ignores the hegemonic po- 
wer of the narrative of national or community belonging (cf. Amit \& Rapport 2002).

Emerging from this discussion transnationality has to be seen as a complex model for identity and belonging without suspending the significance of territory or the nation. In this perspective, places are still important, but they are no longer unambiguous or clearly demarcated. Nyberg Sørensen, for example, has argued that in spite of globalisation and migration, or perhaps specifically as a result of these phenomena, territory does not lose meaning; on the contrary, it gains new significance (Sørensen 2002). In this perspective, migrant groups are simultaneously defined by their relation to the majorities in the receiving and sending country, and by their transnational relations to members and institutions of the group in other countries. Further, this transnational identity is not only a question of loss, despair, longing and nostalgia, but also a complex model for identity and belonging related to the history of the migrants and the interest of the countries involved (Sørensen 2002).

Part of the complexity, as frequently stressed by researchers, is the fact that transnational experiences differ between genders, classes, age groups, etc (Koser 2002, Sørensen 2002). Moreover, if women are not immediately visible in transnational policies and practices, they might even so be constructed differently in the transnational field. As women are constructed as symbols of or participants in keeping up national and ethnic communities (cf. YuvalDavis 1997), they are constructed in similar ways in the transnational field. Floya Anthias and Nira Yuval-Davis distinguish between five different constructs of women in relation to their ethnic group. First, women are biological reproducers of members of their ethnic group. Second, they are reproducers of the boun-daries of ethnic or national groups, which necessitate the establishment of codes determining acceptable sexual behaviour for women, limiting this behaviour within the group. Third, they are transmitters and protectors of cultural and religious values within the group. Fourth, they signify national or ethnic differences, and thus act as symbols of the construction and reproduction of the group. Finally, women are participants in the ethnic, economic, political, and military struggles of the group. The cen-trality of the different constructs changes depending on the group's various historical struggles (Anthias \& Yuval-Davis 1989). By examining the gender constructs of Coptic organisations, we approach an understanding of the struggle for a transnational Coptic identity and belonging.

Anthropologists seem to have discovered the Copts only within the last ten to fifteen years, resulting in primarily community studies, leaving the minority position more or less untouched (cf. Doorn-Harder 1995, Gruber 2003, Thorbjørnsrud 1999). For example, Nora Stene Preston, who studied Copts in London, focuses on the socialisation of children into the church community (Preston 2005). Looking at Copts' opposing strategies - which is also the case here illustrates how gender constructs are utilized in a transnational struggle for legitimising the political strategies of the minority. At the same time, the Coptic case complies with the recommendation of Thomas Faist to examine further different forms of policies constructed as a result of emerging transnational communities. He emphasises that there is no automatic model for transnational policies, but institutionalised practices are central, playing a crucial role in keeping up connections across borders within several generations (Adamson 2002, Faist 1999, 2004).

The analysis below draws on extensive fieldwork done in Egypt, ${ }^{3}$ studies of Coptic homepages from different regions in Europe, the United States, Australia and Canada, and on membership of different transnational Coptic mailing lists. 4 


\section{The Copts OUTSIDE EgYPT}

The transnational Coptic sphere is worldwide and includes Coptic Churches, immigrant communities and migrants present in America, Europe, Australia and Africa. ${ }^{5}$ While both the Coptic Orthodox Church and Coptic secular organisations are present in several European countries, the struggle to define transnational Coptic identity has until now primarily been voiced by American secular Copts and the Coptic Church in Egypt. One of the main discrepancies existing between the organizations is their differing discourses concerning the reasons why Copts live outside Egypt. Without exception, the secular Copts make use of the phrase 'the Coptic Diaspora', whereas the Coptic Church talks about Copts in 'the lands of immigration'. Thus, the secular Copts claim that Copts are living outside Egypt as a result of persecution, while emigration is presented by the church as an opportunity (cf. Stene 1997). In El-Keraza Magazine, the Church's magazine whose audience is Copts outside Egypt, the concept of Diaspora is never used; instead the concepts employed are 'the lands of immigration' or 'the countries of immigration'. 6 'The lands of immigration' are the places where Copts live and especially where Coptic churches have been established. The Coptic priests sent from Egypt to these areas are supposed to be a guarantee that Copts who have emigrated maintain a continuous relationship with the mother church. The perspective of Copts as refugees from a discriminatory system in Egypt is therefore $e x-$ cluded from the official position of the Coptic Orthodox Church, as it plays down the political aspect of emigration and instead highlights the Church as a transnational agent. A systematic examination of their websites reveals that the Coptic churches in Europe, the United States and Canada also do not use the concept of diaspora, at least not in public. ${ }^{7}$

The secular Coptic organisations con- stantly relate the concept of diaspora to the persecution of Copts by Muslim groups and state officials, if not directly, then indirectly by linking the existence of Copts outside Egypt with the situation of Copts in Egypt, thus constructing a causal connection between discrimination and migration.

Looking at the historical facts, minorities are often the first to emigrate in periods of political and social transformation. This is also the case for Egypt, where Jews, Christians and other minorities left the country, especially in the years following independence in 1952. Trustworthy statistics on the number of Copts immigrating to Western countries do not exist, but Copts have immigrated to especially the United States, Canada and Australia. According to the 1991 Coptic Encyclopaedia, 200,000 to 300,000 Copts have migrated to Europe, North America and Australia. Other independent sources estimate that there are approximately one million Copts living outside Egypt, ${ }^{8}$ while the U.S. Copts Association claims to represent over 700,000 Egyptian Christians in the United States alone. ${ }^{9}$

General Egyptian emigration patterns have been characterised by two periods of emigration. The first period was during the era of President Nasser (1952-1970) and the second one was during the open door policies of President Sadat in the early 1970s. No thorough study exists demonstrating the connection between the position of the Coptic minority in a modern Egyptian national state and their emigration. Combined with the United States and Canada's relatively open immigration policy, well-educated Christian Egyptians have migrated with the same overall objectives to gain better life opportunities - as other religious and ethnic groups and individuals. But this objective would of course very likely be affected by the Copts' position in Egypt. After a relatively high degree of political influence in the first half of the cen- 
tury, revolution, nationalisation, and later Islamisation left the Copts in a more uncertain and defensive position (Ibrahim 1996).

The Coptic Orthodox Church is a very active participant in promoting a certain Coptic transnational policy. It is both an old and traditional representative of the Copts vis-à-vis the state in Egypt and a dominant and powerful institution for Christian services in Egypt with more than 95\% of Christians in Egypt belonging to the Orthodox faith. ${ }^{10}$ When Coptic immigrants followed the first wave of immigration to North America in the nineteen sixties, they were dispersed in small numbers all over the continent. Soon the Church in Egypt was asked to send a priest to cater to the spiritual needs of the migrants while the Church in Egypt simultaneously began to show interest in their flocks in America and their spiritual welfare. The first priest was ordained in 1964 and sent by Pope Cyril VI to serve the Copts in North America (Marcos 1994). In the new millennium, there are at least ninety-five churches in the United States, twenty-six in Canada, thirtytwo in Europe, and twenty in Australia. In 1993, Bishop Youssef, the first general bishop outside Egypt, was installed in the United States by Pope Shenouda, and since then, the United Kingdom, Italy, Germany, Austria, South Africa and Australia have had general bishops installed. Coptic monasteries, schools, theological seminaries and villages also exist in the United States, Canada, Australia, Germany, and the United Kingdom. With the establishment of clerical services, Coptic Churches have been inaugurated in places where Coptic immigrants have settled, but the Church has also increasingly tried to extend its influence on a transnational identity policy. This is most obvious when it denounces the strategy of the secular American Copts.

The strongest organisation representing secular Copts is the U.S. Copts Association, founded in 1996 and based in Washington D.C. (a strategic location close to the American Congress). By means of lobbyism the Association promotes its main goal of democracy, religious freedom, and human rights in Egypt. 11 The Association is responsible for a homepage with daily news updates about Copts in the U.S. and Copts in Egypt under the heading 'Representing all Christians of Egypt'.12 As such, the Association and the Church each claims to be the representative of all Copts and, based on this background, gender becomes central for legitimating transnational policies for both organisations.

\section{Symbolising Muslim injustice}

The members of the board of the U.S. Copts organisation, which is secular, are all prominent men with higher education and positions. The women, on the other hand, have been given a central symbolic position in the process of legitimising the Association's policy.

The U.S. Copts Association is trying to mobilise members to engage in the transformation of their country of origin by using political, social or economical instruments (cf. Adamson 2002).13 One way of mobilising members is by exposing the inequality between Copts and Muslims in Egypt, and to that purpose, the image of the Coptic woman as victim of Muslim assault is useful. As mentioned in the introduction, all newer incidences of discrimination or clashes with the police in Egypt have until recently been presented on the Association's homepage under the headline 'Discrimination News'. By focusing on discrimination, the Copts are defined by lack of power in Egypt and by their relation to Muslims as oppressors. Using pictures and short stories, their homepage presents the destinies of a number of Coptic girls under the headline of 'kidnapping'. The narrative describes young Coptic girls being kidnapped by fanatic Islamists with the purpose of either seducing or raping them. After the sexual assault, the girls have been 
forced to marry the offender and to convert to Islam to maintain their honour. As the narrative goes, after conversion, the Muslim man looses interest in the girl because he has fulfilled his goal to conquer non-believers. These Coptic women are obviously portrayed as passive victims of the assault of radical Muslims. A close analysis of the stories, however, shows that what really happened does not always seem very clear. The possibility of the girl falling in love and leaving her parents freely is never mentioned. One could say that parallel to the constructions of a Coptic minority identity, these women are presented as particularly vulnerable and as the quintessence of Coptic minority identity.

Using the stories of forced conversion and discrimination is, at the same time, a valid strategy in the American context. The president of the Association, Michael Meunier, has regular contact with the American Congress and often testifies about the situation in Egypt. ${ }^{14}$ Meunier's representation is not only in accordance with the single most dominant political discourse in the United States that focuses on human rights abuses in the Middle East, but it also confirms the image of the Orient and the Muslim world as non-democratic, fanatical, patriarchal, and the assertion that people with other religious convictions are inferior. In this context, the narrative about how Coptic girls are raped and forced to convert is a key strategy. Thus, Coptic women become a symbol of the general oppression by Muslims of women in general and of the Coptic community in Egypt in particular. By emphasizing the Muslims' assaults as ideologically driven injustice against defenceless Christian women, the Association legitimises its claim for political change in Egypt with reference to Human Rights. The women are constructed as symbols of the Copts' situation as victims in Egypt. In the words of Anthias and Yuval-Davis, the Coptic women signify ethnic differences, and act as symbols in ideological discourses within the group (cf. Anthias \& YuvalDavis 1989).

\section{STAYING CHRISTIAN}

The official transnational representatives of the Church are mostly men and consist of priests, monks, bishops and the Pope of Alexandria due to dogmatic rules of Coptic Orthodoxy. The Church sends male clerical representatives to live and minister to Coptic congregations abroad. Contrary to the secular U.S. Copts Association, however, women are regarded as more active within the Church community.

Conversion to Islam is also a concern of the Church, but contrary to secular Copts, it does not openly blame Muslims. Islam is recognised as the most obvious and, recently, relatively hegemonic alternative in Egypt. According to the Church, what makes Copts leave the Church is just as much changing life patterns in the wake of modernisation, globalisation and secularism. These changes present Copts with other ways of living, including a more laissezfaire relationship to the opposite sex including men and women from other denominations. Changes, which are rendering Copts more disposed to leaving the Coptic community. The threat is, though, not so much Muslims as it is the disintegration of the Coptic community. The strategy of the Church inside Egypt against potential disintegration has been the successful promotion of a religious revival within the Coptic Church over the last fifty years. As such, the Coptic revival has been extended to the lands of immigration and promoted through Sunday schools, in Coptic language training, and by reproducing the iconography and clerical organisation of the Coptic Church in the new churches. The strategy has been to strengthen the relation of Coptic youth to the Church while simultaneously strengthening the boundaries between Copts and non-Copts in relation to social interaction and marriage. 
One element has been to prove the principle of endogamy through religious and dogmatic teaching. His Grace Bishop Moussa, the Coptic youth bishop, is very active in promoting Coptic ideas on family life, not only to the youth in Egypt, but also by spreading the message transnationally in English-language publications, homepages and by participating in youth activities outside Egypt. Thus, the annual European Coptic Youth Conference, which took place in Holland in August 2007, was launched under the auspices of Bishop Moussa.

On the Coptic youth bishop's homepage, marriage and gender relations are prevalent and all kinds of questions and answers are listed in English. Questions like "Is there anything wrong with dating and what is your opinion concerning someone from Australia wanting to marry a person from Egypt?" are raised and answered. The response to questions about whether having relationships before marriage is allowed is in the negative, but:

Abide inside the church, have as many girlfriends and boyfriends in a group atmosphere, and grow in a way that is not only physically, intellectually and spiritually, but also psychologically, in order to choose the correct partner when you are in the stage of selective heterosexuality. Please abide by these three mottos: group relationships, holy relationships, limited relationships ('limited' meaning being aware of your boundaries and not crossing them). ${ }^{15}$

Answers such as this one follow conservative Christian values. In a small booklet called 'Youth and family life' written by youth Bishop Moussa, the chapter on 'Relationships outside the Family' is introduced by the sentence, "These (the relationships) must have principles and boundaries" (Moussa no year, 64). Later, the booklet states that relationships with colleagues, friends and neighbours, "must have manners and spiritual rules, because we suffer from these types of relationships" (Moussa no year, 64). The booklet warns against the bad influence of devastating relationships. It is never mentioned explicitly that the threat is relationships to Muslims which push young Copts into "abandoning constructive, vital principles" (Moussa no year, 65 ).

Bishop Moussa is not an isolated case. Activities in Coptic churches in Europe, such as youth meetings, regularly promote similar ideas about marriage and relations outside marriage. ${ }^{16}$ In addition, if young Copts marry outside the Church, the likely consequence is expulsion from the Church, which is most often practiced in Egypt, while intervention of this type outside Egypt is usually less definitive. A young Coptic man born in Egypt, but now living in a European country, told me how he when he married a European woman outside the Church - was degraded and denied his clerical status, which he had achieved after several years of faithful service in the Church in Egypt and in Europe.

Clear restraints for choosing one's marriage partner is supported by a definition of Coptic marriage as a sacrament and thereby in unity with God (Banoub \& Assad 1998, Moussa no year). As such, men and women have equal responsibility in treasuring the marriage, but with different specific obligations for women concerning the biological reproduction of the Coptic community. If the idea of marriage as a sacrament is to prevent young Copts from marrying outside the Church, it is obviously important to convince both sexes of the importance of their religion. In this regard, the inclusion of young people in the clerical hierarchy has been one method and constitutes an area where gender differences become prevalent.

PART OF THE CLERICAL HIERARCHY

One way to keep young people in the 
Church, at least until true Christian marriage is entered into, once stated as the finest goal by the youth bishop, is to involve them in the work within the Church. The Church could have chosen to redefine the role of women as only that of a mother and wife, but instead encourages women to educate themselves and participate in Christian community work. They become committed to the Church through positions as Sunday school teachers, but also as nuns, deaconesses serving in the different social activities of the Coptic Church, and as consecrated virgins taking part in social and educational activities of the dioceses. Becoming a martyr, the ultimate sacrifice for God in agreement with the principle of leaving everything to God, is not handed over to men alone. Women can also become martyrs and are portrayed in stories about Coptic martyrs, which recently have gained new life in, for instance, films in which historical women martyrs are presented as models for Coptic women of today. Men, on the other hand, function as Sunday school teachers, deacons, monks, priests, priest-monks and bishops. Dina ElKhawaga has termed the process of including laymen in Church work the clericalisation of the Copts. By mobilizing tens of thousands of young people to "serve" in the parishes, new value is given to the pastoral and pedagogical work of the church (El-Khawaga 1997, 1998). The different positions occupied by the new clergies are supportive of a strong hierarchy and have strengthened a strongly centralised church (El-Khawaga 1997, 1998, Thorbjørnsrud 1999, 106).

In other words, negotiated within a centralised and hierarchical structure, activities become gender specific despite the active new responsibilities given to women. The Church is constructing the Coptic identity as spiritually assertive, gender equal in God's eyes but with differentiated gender obligations within the Church, supporting individuals in their professions as promoters of the faith but restraining individuals in their choice of civil status. The Church's constructs of the Copts support the power of the Church, but are at the same time in accordance with the political situation in Egypt, where religion is not only socially accepted, but also a legally constrained identity. The limitations are that any demands raised with reference to religion will be rejected by the state as a threat to internal stability and as being against the security of the state. It is in this context that it is possible to understand Pope Shenouda's denial of Copts constituting a minority. Instead he is accentuating the identity of Copts as equal and authentic Egyptian citizens. As identity policy this is supported by the clericalisation of the youth. As one young clerk in the Church told me, when I asked, if it is not important to fight for one's right, 'No, the important thing is to serve God!' (Galal 2006).

\section{TwO TRANSNATIONAL STRATEGIES}

The gender constructs pointed out in the above illustrate how two Coptic organisations in their separate ways try to maintain transnational ties and sense of community among Copts. Both organisations have a clear idea about their own assignment vis-àvis the Copts. On the one hand, the Church sees itself as the protector of Coptic identity transnationally. Thus, a Coptic Canadian priest argues: "A Copt can hardly survive when he is severed from his land, but cannot survive if he is separated from his Church" (Marcos 1994). On the other hand, secular Copts outside Egypt see themselves as saviours of Copts inside Egypt, claiming that, "...the only hope Copts have now of surviving inside Egypt, is the Copts outside Egypt."17

It is obvious that both institutions see themselves as transnational guardians of the Coptic community. They find that the borders between Muslims and Copts are contested and important to protect, though for 
different reasons. Both the secular and religious transnational strategies are closely connected to the status of Copts as a minority in Egypt. The transnational policies presented use gender constructs to legitimise minority strategies in Egypt. These minority strategies, however, differ just as the transnational strategies do. While the Coptic Church is trying to expand its influence from Egypt abroad wherever Copts reside, the secular Copts are trying to gather all their strength to change minority politics in one specific place, Egypt. Apparently, the Church's strategy is to create a greater transnational space for Coptic communities; the secular Copts' strategy is to use the transnational reality to create a space in Egypt with better possibilities for living a Coptic life. Therefore, the Church establishes codes that determine women's and men's acceptable sexual behaviour, limiting this behaviour within the group regardless of where the Copts live, whereas the U.S. Copts Association puts pressure on the Egyptian state to protect the boundaries between Muslims and Copts. The Coptic women abused by Muslim men have become a symbol of the neglect of the State to protect these boundaries.

\section{AT WHOSE EXPENSE?}

The Copts' transnational strategies are, as argued, closely connected to different minority strategies. The Coptic Church and the U.S. Association's constructs of gender illustrate how the empowerment embedded in their transnational strategies is closely related to the minority position in Egypt. At the same time the gender constructs reveal internal injustices and inequality within the Coptic community. The focus on empowerment of the community seems to be at the expense of individual rights. Thus, in December 2004, when the wife of a Coptic priest wanted to divorce her husband, well aware that divorce for Orthodox Christians in Egypt is almost impossible, she tried to convert to Islam. In the wake of public attention, the woman was taken into custody and handed over to the Church. She was brought to a monastery, advised by the Pope himself, and kept under house arrest in the monastery for several months. As one journalist in the Egyptian newspaper Al-Ahram Weeks commented, "The government's concern with sectarian strife is such that the angry Coptic mob is appeased at the expense of individual Copts' rights" (Morgan 2005, 1). The actions of the Church are no less controversial than the government's. The solution of forcing the woman into passivity is in accordance with the Church's emphasizing of spiritual unity and the maintenance of boundaries and this seems to be at the expense of individual rights of a single person. The U.S. Copts Association reported the incidence as another attempt of forced conversion, which was not the case according to the Coptic Church. In this regard, the U.S. Copts Association also ignored the internal injustice done to individuals, including the violation of the human rights of women in the Coptic community. 18

Transnational clericalisation does not only strengthen the Church as an institution, but also the Copts' national belonging to Egypt. The Coptic faith is deeply rooted in Egyptian history and mythology, an aspect that is promoted by the Church and reflected in the practice of preferring Egyptian-born priests to serve abroad. By going transnational, so to speak, the Church creates a space - a counter public - partly freed of its status as a minority. The power of the Church within Egypt is built on this strategy. It is obviously a position that it does not want secular Copts to undermine. Moreover, the Church's strategy seems, at least partly, to outdo the secular one.

Thus, the headline 'Discrimination News' is no longer available on the U.S. Copts Association homepage and a new homepage has been launched that plays down political visual effects. Instead, the 
homepage provides a smoother visual impression in which a Christian cross has a central position between the Nile and the Statue of Liberty. ${ }^{19}$ Perhaps the Association has realised that the Church is not to be ignored and has taken into consideration the influence of religious communities in the United States as well as the weakness of its supporters in Egypt.

Two conclusions are presenting themselves. On the one hand, as long as the transnational policy is defined within the framework of a minority position, it leaves Coptic women in a position where the construct of them as symbols, reproducers and embodiments of the community becomes dominant. On the other hand, the inclusion of both young women and men living outside Egypt in the Church hierarchy possibly gives hope for changes emanating from within the Church and contesting the strict and conservative constructs of Coptic transnational identities.

\section{Notes}

1. http://www.copts.net/descrimination.asp (accessed 09-03-2005).

2 . There are, of course, many approaches to the study of minorities; here, I elaborate the research perspective presented in Galal (2006).

3 . I conducted fieldwork on the Coptic Church in 1992, 1994, 1998, and have followed up on my findings in 2006 .

4. I am member of a Coptic-Danish, a CopticAmerican and two Coptic-Egyptian mailing lists. 5. While Copts in the Western countries are mostly immigrants from Egypt and their descendents, Copts in Africa - except for Arab countries and Ethiopia - are mostly converts and the result of Coptic missions.

6. See, for instance, el-Keraza Magazine (2004a), where the rev. fathers arriving from the lands of immigration to attend the Pope's anniversary celebration are all mentioned by name; and el-Keraza Magazine (2004b), which talks about Church councils in the lands of immigration.

7. The only exception I have found until now is in a speech by Abba Seraphim, Metropolitan of Glas- tonbury, printed in The Glastonbury Bulletin, no. 92 March 1996,

http://groups.yahoo.com/group/arbible/message/2368 (Accessed 15-10-2005). It is worth mentioning, however, that the Metropolitan was the Metropolitan of the Orthodox Church of the British Isles before being reunited in 1994 with the Coptic Orthodox Church and being consecrated as a Metropolitan in the Coptic Patriarchate. As a result, he is not originally an Egyptian or socialised into the narratives of the Coptic Church. 8. For a discussion on numbers, see Stene (1997). 9. Copts.com at

http://www.copts.net/print.asp?id=618 (accessed 15-02-2005).

10. The number of Christians in Egypt is very uncertain and varies from $6 \%$ to $15 \%$ of the population.

11. Copts.com at

http://www.copts.net/print.asp?id=618 (accessed 15-02-2005).

12. http://www.copts.com/english/ (accessed 20-09-2007).

13. Other transnational secular Coptic institutions are behind 'the Coptic Charter' and the International Coptic Symposium held in Zürich 2004. 14. For instance, Michael Meunier gave testimony afort the Congressional Human Rights Caucus in May 2007.

http://www.copts.com/english/NewsDetails.aspx?id=rLKFjC5CAiC9uIhevRjLQuw5mlT5mtnF86hLuuuxaJU=\&Type $=$ S7hWEHn9mYMPH12 EhfzVpmjf4ZDifPT5TC6cPW $/ \mathrm{IhIk}=($ accessed 27-05-2007).

15 .

http://www.youthbishopric.com/questions/ql.as p\#What $\% 20$ is\%20your\%20opinion\%20concerning $\% 20$ someone $\% 20$ from $\% 20$ Australia $\% 20$ wanting\%20to $\% 20$ marry $\% 20 \mathrm{a} \% 20$ person $\% 20$ from $\% 20 \mathrm{Eg}$ ypt (accessed 27-05-2007).

16. See, for instance, St. Mark's Church in London, where a lecture was given on 'God's plan with marriage', http://www.stmark.org.uk/images/stories/powerpoint/Understanding\%20God $\% 92$ s $\% 20$ plan $\% 20$ for $\% 20$ Marriage $\% 20$ and $\% 20$ the $\%$ 20role\%20of\%20sex\%20in\%20it.pps (accessed 1909-2007).

17. http://www.copts.net/coptic_center.asp (accessed 15-02-2005). The statement appears in a policy paper directed at the foundation of a Coptic centre, where the mobilisation of the diaspora is a precondition for the realisation of this type of centre.

18. Even when a secular Coptic Australian woman raised her voice at a Coptic conference in Switzer- 
land, the Muslims were given the sole blame (cf. Ghaly 2006).

19. http://www.copts.com/english/ (accessed 01-06-2007).

\section{REFERENCES}

- Adamson, Fiona B. (2002): "Mobilizing for the transformation of home: Politicized identities and transnational practices", in Nadje Al-Ali \& Khalid Koser (eds.): New approaches to migration?

Transnational communities and the transformation of home. Routledge, London and New York.

- Amit, Vered \& Rapport, Nigel (2002): The trouble with community: Anthropological reflections on movement, identity and collectivity. Pluto Press, London and Sterling, VA.

- Anthias, Floya \& Yuval-Davis, Nira (1989): "Introduction", in Floya Anthias \& Nira Yuval-Davis (eds.): Woman - nation - state. Palgrave Macmillan, London.

- Banoub, Hedy \& Maurice Assad (1998): The image of Coptic women in Coptic tradition. St. John the Beloved Publishing House, Cairo.

- Cohen, Robin (1997): Global Diasporas: An introduction. UCL Press, London.

- Doorn-Harder, Pieternella van (1995): Contemporary Coptic nuns. University of South Carolina Press, Columbia.

- El-Keraza Magazine (2004a), 19-11-2004. Issues no. 35,36 .

- El-Keraza Magazine (2004b), 03-12-2004. Issues no. 37, 38 .

. El-Khawaga, Dina (1997): "The laity at the heart of the Coptic clerical reform", in Nelly van Doorn Harder \& Kari Vogt (eds.): Between desert and city: The Coptic Orthodox Church today. The Institute for Comparative Research in Human Culture.

Novus forlag, Oslo.

. El-Khawaga, Dina (1998): "The political dynamics of the Copts: Giving the community an active role", in Andrea Pacini (ed.): Christian communities in the Arab Middle East: The challenge of the future. Clerendon Press, Oxford.

. Faist, Thomas (1999): "Transnationalization in international migration: Implications for the study of citizenship and culture", in Ali Rogers (ed.): Transnational communities programme working paper series, WPTC-99-08,

http://www.transcomm.ox.ac.uk/working\%20papers/faist.pdf.

- Faist, Thomas (2004): “The transnational turn in migration research: Perspectives for the study of politics and polity", in Maja Povrzanovic Frykman (ed.): Transnational spaces: Disciplinary perspectives. International Migration and Ethnic Relations (imer), Malmö University, Malmö.

. Galal, Lise Paulsen (2006): "Anerkendes af hvem og for hvad? Et Minoritetsperspektiv", in Morten Sandberg, Simon Laumann Jørgensen \& Steen Brock (red.): Kulturlighed: Temaer omkring kulturel identitet, foranderlighed og anerkendelse. Philosophia, Århus.

. Ghaly, Nadia (2006): “Terrorism against Coptic women", in Martyn Thomas, Adly A. Youssef, Heinz Gstrein \& Paul Meinrad Strässle (eds.): Copts in Egypt. A Christian minority under siege. G2W-Verlag, Zürich, V\&R, Göttingen.

. Grossberg, Lawrence (1998 (96)): "Identity and cultural studies: Is that all there is?", in Stuart Hall \& Paul du Gay: Questions of cultural identity. Sage Publications, London.

- Gruber, Mark (2003): Sacrifice in the desert: A study of an Egyptian minority through the prism of Coptic monasticism. University Press of America, Lanham, New York, Oxford.

- Ibrahim, Saad Eddin (1996): The Copts of Egypt. Minority Rights Group, London.

- Koser, Khalid (2002): "From refugees to transnational communities?", in Nadje Al-Ali \& Khalid Koser (eds.): New approaches to migration? Transnational communities and the transformation of home. Routledge, London and New York.

- Malkki, Liisa (1992): "National Geographic: The rooting of peoples and the territorialization of national identity among scholars and refugees", in Cultural Anthropology 1992/(1) 7.

- Marcos, Marcos A. (1994): The Copts of Canada: A shining star in a galaxy of diversified celestial bodies or the founding of the Coptic Orthodox Church in North America, http://www.stmark.toronto.on.coptorthodox.ca/ copts.asp (accessed 02-03-2005).

- Morgan, Maggie (2005): "Samir Morcos: The mirror of the Copt", in Al-Abram Weekley 23 - 29 June, no. 748, http://weekley.ahram.org.eg/print/2005/748/p rofile.htm (accessed 07-10-2005).

- Moussa, H.G. Bishop (no year): Youth and family life. Coptic Orthodox Patriarchate, Bishopric of Youth, Cairo.

- Preston, Nora Stene (2005): Engler i platåsho. Religiøs sosialisering av koptisk-ortodokse barn $i$ London. Unipub forlag, Oslo.

- Stene, Nora (1997): "Into the lands of immigration", in Nelly van Doorn-Harder \& Kari Vogt (eds.): Between desert and city: The Coptic Orthodox Church today. Novus forlag, Oslo. 
. Sørensen, Ninna Nyberg (2002): "New landscapes of migration? Transnational migration between Latin America, the U.S. and Europe", in Bodil Folke Frederiksen \& Nina Nyberg Sørensen (eds.): Beyond home and exile: Making sense of lives on the move. Occasional Paper no. 23. International Development Studies, Roskilde University, Roskilde.

- Thorbjørnsrud, Berit (1999): Controlling the body to liberate the Soul: Towards an analysis of the
Coptic Orthodox Concept of the body. Unipub Forlag/Akademika AS, Oslo.

- Yuval-Davis, Nira (1997): Gender and nation. Sage, London.

Lise Paulsen Galal

Assistant Professor

Department of Culture and Identity

Roskilde University 